\title{
DO EXPENDITURES OTHER THAN INSTRUCTIONAL EXPENDITURES AFFECT GRADUATION AND PERSISTENCE RATES IN AMERICAN HIGHER EDUCATION
}

\author{
Douglas A. Webber \\ Ronald G. Ehrenberg \\ Working Paper 15216 \\ http://www.nber.org/papers/w15216
NATIONAL BUREAU OF ECONOMIC RESEARCH
1050 Massachusetts Avenue
Cambridge, MA 02138

August 2009

Our research has been supported by grants to the Cornell Higher Education Research Institute (CHERI) from the Andrew W. Mellon Foundation, the Atlantic Philanthropies, the TIAA-CREF Institute and the Lumina Foundation for Education. However, the views expressed here are solely our own.

NBER working papers are circulated for discussion and comment purposes. They have not been peerreviewed or been subject to the review by the NBER Board of Directors that accompanies official NBER publications.

(C) 2009 by Douglas A. Webber and Ronald G. Ehrenberg. All rights reserved. Short sections of text, not to exceed two paragraphs, may be quoted without explicit permission provided that full credit, including $\odot$ notice, is given to the source. 
Do Expenditures Other Than Instructional Expenditures Affect Graduation and Persistence

Rates in American Higher Education

Douglas A. Webber and Ronald G. Ehrenberg

NBER Working Paper No. 15216

August 2009

JEL No. I22,I23

\begin{abstract}
During the last two decades, median instructional spending per full-time equivalent (FTE) student at American 4-year colleges and universities has grown at a slower rate than median spending per FTE student in a number of other expenditure categories including academic support, student services and research. Our paper uses institutional level panel data and a variety of econometric approaches, including unconditional quantile regression methods, to analyze whether these non instructional expenditure categories influence graduation and first-year persistence rates of undergraduate students.

Our most important finding is that student service expenditures influence graduation and persistence rates and their marginal effects are higher for students at institutions with lower entrance test scores and higher Pell Grant expenditures per student. Put another way, their effects are largest at institutions that have lower current graduation and first year persistence rates. Simulations suggest that reallocating some funding from instruction to student services may enhance persistence and graduation rates at those institutions whose rates are currently below the medians in the sample.
\end{abstract}

Douglas A. Webber

Cornell Higher Education Resarch Institute

271 Ives Hall

Ithaca, NY 14853-3901

daw225@ cornell.edu

Ronald G. Ehrenberg

Cornell Higher Education Research Institute

271 Ives Hall East

Ithaca, NY 14853-3901

and NBER

rge2@cornell.edu 


\section{Introduction}

Rates of tuition increases in both private and public higher education that continually exceed inflation, coupled with the fact that the United States no longer leads the world in terms of the fraction of our young adults who have college degrees, have focused attention on why costs keep increasing in higher education and what categories of higher education expenditures have been growing the most rapidly. In a series of publications, the Delta Cost Project has shown that during the last two decades median instructional spending per full-time equivalent (FTE) student in both public and private 4year colleges and universities in the United States grew at a slower rate than median expenditures per FTE student in many other categories of expenditures (research, public service, academic support, student services, and scholarships and fellowships). ${ }^{1}$ Similarly, the Center for College Affordability and Productivity reports that during the same time period, managerial and support/service staff at colleges and universities grew relative to faculty. $^{2}$

Do such changes reflect increased inefficiency and waste or do some non instructional categories of employees and expenditures contribute directly to the educational mission of American colleges and universities? In this paper, we use institutional level panel data and an educational production function approach to estimate whether various non instructional categories of expenditures directly influence graduation and persistence rates of undergraduate students in American colleges and universities. We find, not surprisingly, that the answer is several of these expenditure categories do influence students' educational outcome, but that the extent that they matter varies with

\footnotetext{
${ }^{1}$ Jane Wellman et. al. (2008), Figure 18 and Jane Wellman et. al. (2009), Figure 8

2 Tamar Lewin (2009)
} 
the socioeconomic backgrounds and the average test scores of the students attending the institutions.

\section{Educational Production Functions}

The educational production function literature has its roots in the study of the impact of school resources on educational outcomes in elementary and secondary education and goes back to the 1960s Coleman Report. ${ }^{3}$ An extraordinarily large number of studies have used non experimental and experimental (most notably from the Tennessee STAR experiment) data to test whether expenditures per student or class size influence students test score gains and graduation rates. ${ }^{4}$

A parallel literature has developed in higher education and has used institutional level data to study the impact of higher education expenditures on persistence and graduation rates. ${ }^{5}$ With few exceptions, expenditures per student have not been disaggregated into different functional categories of expenditures in this research. The few studies that have separated out expenditures into functional categories, such as instruction, student services, academic support, and research, have not reached a consensus on whether expenditure categories other than instruction influence persistence and graduation rates. ${ }^{6}$ The lack of consistency or their results has been attributed to methodological differences in the studies, including their use of different relatively small samples of institutions. ${ }^{7}$

\footnotetext{
${ }^{3}$ James Coleman et. al. (1966)

${ }^{4}$ A comprehensive survey and critical evaluation of this literature is found in Ronald. G. Ehrenberg, Dominic J. Brewer, Adam Gamoran and J. Douglas Willms (2001)

5 See, for example, Hans De Groot et. al. (1991), and Robert Dolan and Robert Schmidt (1994).

${ }^{6}$ For example, Alexander Astin (1993) found that student service expenditures positively influenced persistence, John F. Ryan (1994) found that academic support expenditures were related to persistence but student service expenditures were not, and Ann Gansemer-Topf and John Schuh (2006) found that persistence rates were positively related to academic support services, but negatively related to student service expenditures.

${ }^{7}$ Gary R. Pike, John C. Smart, George D. Kuh and John C. Hayek (2006). These authors also analyze the effects of different expenditure categories on student engagement
} 
We contribute to this literature in a number of ways. First, we use panel data for a national sample of 1160 4-year colleges and universities. While most of the data we use were originally collected as part of the Integrated Postsecondary Education Data System (IPEDS), these data have been carefully compiled, edited for consistency, and then made available to researchers by the Delta Cost Project (www.deltacostproject.com ). Second, we stratify the data by type of institution (baccalaureate, masters, doctoral), and, most importantly, by the test scores of entering first-year students and the average Pell Grant dollars received by FTE undergraduate students at the institution to see how the impact of different expenditure categories on outcomes varies across types of students and institutions. Third, we build on the work of Gary Blose, John Porter and Edward Kokklenberg (2007), who have shown that estimation of higher educational production functions that do not control for the distribution of degrees granted at an institution across fields yield misleading estimates of the impact of measured instructional expenditures per students on graduation rates, because the cost of educating students varies widely across majors. Finally, we employ a variety of econometric methods, including unconditional quantile regression, and simulate how the reallocation of resources from instructional to other uses would influence graduation and persistence rates.

\section{Descriptive Statistics and the Definitions of Expenditure Categories}

Table 1 presents descriptive statistics for the institutions in our sample during the 2002-03 to 2005-06 academic years on the six-year graduation rate of entering full-time first year students, the persistence rate of full-time first year students, the median SAT scores of entering first-year students, the average Pell Grant dollars received per FTE 
undergraduate student, and four categories of expenditures per FTE student. The data are reported for the entire sample of 1160 institutions, for subsamples of lower and higher median SAT scores and lower and higher levels of Pell Grants per FTE, and by institutional type. The expenditure variables for each year have been adjusted to reflect the price level in 2006.

The average six-year graduation rate for the institutions in our sample was 55 percent. Graduation rates are higher at high SAT institutions than they are at low SAT institutions, and higher at institutions with lower levels of Pell Grant dollars per FTE student than they are at institutions with higher levels of Pell Grant dollars per FTE student. They also vary by institutional type and form of control and are higher at private institutions than they are at public institutions. The average persistence rate of full-time first-year students at the institutions in our sample was 77 percent and the pattern of persistence rates across the institutions mirrors the pattern of graduation rates.

The four expenditure categories that we focus on in this paper are instructional expenditures, academic support expenditures, student service expenditures, and research expenditures. Detailed definitions of the content of each of these categories are found in the Integrated Postsecondary Education Data System online glossary (http://nces.ed.gov/ipeds/glossary ); we summarize them only briefly here. Instructional expenditures include expenses of activities directly related to instruction including the proportion of faculty salaries going to departmental research. Researchers and policymakers look at instructional expenditures often are not aware that departmental research, research that is not externally funded or separately budgeted by academic institutions, is included in this category; a point that we will return to shortly. 
Average instructional expenditures per FTE student were $\$ 9689$ for the institutions in our sample (column 1). The wide standard deviation of instructional expenditures per student $(\$ 31,352)$ is due to very high expenditure levels at a small number of wealthy private institutions. Mean instructional expenditures per FTE student are twice as high at the higher SAT score institutions in our sample $(\$ 12,966)$ than they are at the lower SAT score institutions (\$6087) and similarly are almost twice as high at institutions with lower levels of Pell Grant expenditures per FTE student $(\$ 12,592)$ than they are at institutions with higher levels of Pell Grant expenditures per student (\$6701). Put simply, higher test score students from higher income families attend institutions with higher instructional expenditures per student than other students do. Average instructional expenditures per student also are higher at bachelors and doctoral institutions than they are at masters institutions and higher at private institutions than they are at public institutions. However, the variability of instructional expenditures within categories is often very large.

Academic support expenditures are expenses that support the instruction, research and public service missions of the university. They include libraries, museums, academic computing (if it is not separately budgeted), media services and curriculum development. The mean level of these expenditures per FTE student was $\$ 2456$ for the institutions in our sample (column 1), but again the standard deviation of this variables is very large. Academic support expenditures per student are over twice as large at both the higher SAT institutions than they are at the lower SAT institutions and at the lower Pell Grant expenditure per student institutions than they are at the higher Pell Grant expenditure per student institutions in our sample. 
Student service expenditures include expenses for the admissions and registrars activities, for activities that contribute to students' emotional and physical well-being and to their intellectual, cultural and social development outside of the institution's formal instructional program. Examples here include student organizations, intramurals, student health services (including psychological counseling) and supplemental instruction (such as tutoring programs). These expenditures averaged \$2779 per FTE student in our sample, but were higher at higher SAT institutions (\$3514) than they were at lower SAT institutions(\$1980) and higher at institutions with lower levels of Pell Grant expenditures per FTE (\$3348) than they were at institutions with higher levels of Pell Grant expenditures per FTE (\$2193).

Finally research expenditures are expenses for activities that are specifically organized to produce research outcomes. Typically these include externally sponsored research and separately budgeted research centers and institutes financed out of institutional funds. Research expenditures per FTE students averaged \$2682 in our sample, but there were again wide variations in this category of expenditures across institutions and institutional categories. In particular, average research expenditures per FTE student were much higher at higher SAT institutions (\$4045) than they were at lower SAT institution (\$704) and similar much higher at institutions with lower Pell Grant expenditure per student (\$3738) than they were at institutions with higher Pell Grant expenditures per student (\$1299).

Our goal is to estimate the extent to which these four different categories of expenditures influence undergraduate students' graduation rates and how these influences vary across different types of institutions. Our expectations are that instructional 
expenditures per student will be important for all categories of institutions, but that the importance of student services and academic support expenditures may vary across institutions. In particular, students with lower entrance test scores and those coming from families with lower economic resources may have greater need for the services that academic support and student service expenditures provide and thus that these expenditure categories should influence graduation rates more for students at lower SAT and higher Pell Grant expenditure per student institutions.

Why should research expenditures per student influence graduation rates once one control for the levels of the other expenditure categories? Here our intuition is that the institutions with high levels of funded research expenditures per student are also the institutions that have a greater share of their reported instructional expenditures in the form of departmental research. To the extent that we are correct and faculty time spent on departmental research reduces the time available for instruction, this suggests that higher levels of funded research expenditures per student may appear to have a negative effect on graduation rates, when instructional expenditures per student are held constant, because of their correlation with the unobserved (to the researcher) departmental research expenditures. ${ }^{8}$

\section{Econometric Analyses}

Our initial econometric approach involves estimating equation (1) using a panel of four years (2002-2003 to 2005-2006) data for 1160 institutions for which we have

\footnotetext{
${ }^{8}$ We are grateful to Professor Emeritus Charles Schwartz of the Department of Physics at the University of California at Berkeley for raising with one of us the issue of whether the inclusion of departmental research in instructional costs leads researchers and administrators to overestimate the extent to which institutional resources are being devoted to undergraduate instruction; this stimulated us to provide the explanation above as to why increases in budgeted research expenditures might have a negative effect on graduation rates, when instructional expenditures were held constant.
} 
complete data on expenditures, student and institutional characteristics and graduation rates.

(1) $\ln \left(g_{i t} /\left(1-g_{i t}\right)\right)=a_{0}+a_{1} S T U_{i t}+a_{2} I N S_{i t}+a_{3} A_{C A} A_{i t}+a_{4} R E S_{i t}+b X_{i t}+C Y_{i}+d Z_{t}+u_{i t}$

Here $g_{i t}$ is the 6-year graduation rate of school $i$ as of year $t$ for students who entered the institution as full-time first-year students 6 years earlier. $\mathrm{STU}_{\mathrm{it}}, \mathrm{INS}_{\mathrm{it}}, \mathrm{ACA}_{\mathrm{it}}$, and $\mathrm{RES}_{\mathrm{it}}$ are the averages, respectively, of the previous 6 years natural logarithm of the institution's expenditures per full-time equivalent (FTE) student on student services, instruction, academic support services and research (all values have been expressed in 2006 dollars). ${ }^{9}$ The $\mathrm{X}_{\mathrm{it}}$ are a vector institutional level control variables that vary over time, while the $Y_{i}$ and $Z_{t}$ are a vector of institutional level control variables that do not vary over time and a series of year dichotomous variables, respectively. The $\mathrm{u}_{\mathrm{it}}$ is a random error term and the a, b, c, and d are coefficients to be estimated.

The dependent variable is the log odds ratio of the graduation rate to constrain the predicted value to lie between 0 and 1 . The logarithmic transformation of the expenditure variables is used to deal with the skewed nature of their distributions and to allow for nonlinear impacts of each variable on the graduation rate.

The institutional level control variables include characteristics of the institution and its students that might be expected to influence graduation rates. These include both the average of the $25^{\text {th }}$ and $75^{\text {th }}$ percentile of the SAT scores for the institution's entering first-year class and the average (over the previous six years) Pell Grant dollars per FTE

\footnotetext{
${ }^{9}$ In preliminary analyses we also experimented with including in the model various additional categories of expenditures per student, as well as a composite of all other expenditures per student variable. However, these variables were not consistently statistically significant from zero, nor did their inclusion impact upon the coefficients of the expenditure categories that are of primary interest to us.
} 
received by the institution's undergraduate students. ${ }^{10}$ Similarly, they include the percentages of the institution's undergraduate students that were male, African American, Hispanic American, Asian American, and American Indian, as well as whether the institution was a Historically Black College or University. ${ }^{11}$

Also included among the institutional control variables are the number and the square of the number of undergraduate and graduate students enrolled at the institution (to allow for economic of scale and to control for differing costs of undergraduate and graduate education) and the share of undergraduate degrees awarded by the institution in the year in each of 15 different fields. ${ }^{12}$ These shares are included to control both for differences in the difficulty of getting a degree in different fields and differences in the institutional costs of educating students in each of the fields. Finally, dichotomous variables for the type of institution (bachelors, masters or doctoral) are included, as are year dichotomous variables (to control for macro variables such as the state of the labor market that may influence students' decisions to remain in or leave college.

Because there is very little variability within an institution in the expenditure share variables during the four years for which we have graduation rate data panel data method, such institutional fixed effects, could not be employed. Instead we initially pool our data across all years and all types of institutions and weight each observation by its undergraduate enrollment level (because larger institutions should have less random

\footnotetext{
${ }^{10}$ SAT data come from the College Board's Annual Survey of Colleges: Standard Research Tape with a standard crosswalk used to convert ACT scores to SAT scores for those institutions that reported only ACT scores

${ }^{11}$ Studies that have shown that African American students have higher graduation rates, ceteris paribus, at HBCUs include Jill Constantine (1995). Ronald G. Ehrenberg and Donna Rothstein (1994) and Roland G. Fryer Jr. and Michael Greenstone (2007)

${ }^{12}$ The degree data come from the IPEDs Completions Survey and the categories used are Agriculture, Architecture, Humanities, Communications, Education, Engineering, Legal, Biological Sciences, Mathematics, Military, Physical Sciences, Social Sciences, Performing Arts, Business and Health (with the omitted category being all other fields).
} 
variation in their graduation rates). ${ }^{13}$ Our estimation method also takes account of the fact that the error terms for the same institution may be correlated across years.

Table 2 presents estimates of variants of equation (1) for our entire sample. The estimates presented in column (1) are for a model in which only the expenditure categories and the average level of Pell Grant expenditures per student are included. Higher Pell Grant expenditures per student are associated with lower graduation rates and higher levels of each of the expenditure categories are associated with higher graduation rates.

Columns (2) and (3) present estimates of more complete models. Other factors held constant, increases in average SAT scores and the share of students that are Asian American are associated with higher graduation rates, while increases in the share of students that are male, African American or American Indian are associated with lower graduation rates. As the prior literature has found, other factors held constant, Historically Black Colleges and Universities have higher graduation rates. Most important, in the more complete models the only expenditure categories that have statistically significant positive impacts on graduation rates are those for instruction and student services. Moreover, as we postulated, increases in budgeted research expenditures per student adversely impact upon graduation rates.

Because the model we have estimated is nonlinear, calculation of the marginal effects of increasing expenditure levels in any expenditure category on the graduation rate depends upon the coefficients of all of the variables in the model and the values of all of the explanatory variables for the institution. To simulate what the impact of an

\footnotetext{
${ }^{13}$ Because we have weighted each observation by undergraduate enrollment, including undergraduate enrollment measures in our regression specification do not add any more information in a regression sense. The results both with and without a linear and quadratic undergraduate enrollment term were the same.
} 
increase in expenditures in any category of $\$ 500$ per student would be on the graduation rate, we perform the following calculation.

1. Given the values of the explanatory variables for an institution/year observation and the estimated coefficients of the model, we obtain a predicted value of the graduation rate for the institution/year observation.

2. We add $\$ 500$ per student to the institution/year observation for the particular expenditure category (e.g. student services) and redo the calculation

3. We take the difference between the predicted graduation rate in step 2 and that in step 1 and then average that over all institution/year observations in our sample

The first column of table 3 presents the coefficient estimates for the different expenditure categories and the standard errors of these coefficient estimate that we obtained from the most general specification found in table 3 . Then the bottom panel for each expenditure category, row titled marginal effects, presents the results of the calculation described above. In the remaining columns of table 3, we present the coefficients, standard errors of the coefficients and the marginal effects that we obtained when we re estimated models for seven different subsamples of observations -lower and higher SAT institutions, lower and higher Pell Grant recipient institutions, bachelors, masters and doctoral institutions, and public and private institutions.

Focusing first on the overall sample results. Ceteris paribus, an increase in student services expenditures of $\$ 500$ per student, on average, would increase an institution’s six- 
year graduation rate by 0.7 percentage points. Similar increases in instructional expenditures and academic support services expenditures would, on average, increase the graduation rate by about 0.3 percentage points, while an increase in budgeted research expenditures of the same amount would decrease the graduation rate by 0.7 percentage points; recall that we hypothesize that this latter result reflects a greater share of instructional expenditure being devoted to departmental research when budgeted research expenditures are higher.

Given the fiscal condition that our nation's academic institutions are facing, it is probably not realistic to expect that institutions will easily be able to increase expenditures per student in any category by $\$ 500$. So in the bottom row of the table that it titled "Reallocate" we perform a different simulation. Here we ask if one were to reduce an institution's institutional expenditures per student by $\$ 500$ and simultaneously increase its student services expenditure per student by the same amount, what would the impact be on the institution's graduation rate? The simulation methodology is very similar to that described above. On average, our simulation suggests that this type of change would increase an institution’s graduation rate by 0.3 percentage points.

This finding is one that neither faculty around the country worried about declining funding for faculty positions nor critics of higher education who point to the wasteful growth of expenditures on non instructional uses are likely to be happy about. But our key words are "on average”. What is true on average is not necessarily true for all categories of institutions so in the remaining columns of the table we pursue our analyses further for various subsamples of the data. 
Turning first to a comparison of lower and higher SAT institutions, the marginal effect on graduation rates of increasing student service expenditures by $\$ 500$ per student is much larger at institutions whose students have lower SAT scores (1.7 percentage points) than it is at institutions whose students have higher SAT scores (0.3 percentage points) (columns 2 and 3). The marginal impact of increasing instructional expenditures per student by $\$ 500$ is roughly the same at the two types of institutions; 0.4 and 0.3 percentage points, respectively. Not surprising then, when we simulate the impact of simultaneously increasing student service expenditures by $\$ 500$ per student and reducing instructional expenditures by the same amount, graduation rates are estimated to increase by 1.3 percentage points at the low SAT schools, but to remain essentially unchanged at the higher SAT schools. Put simply, our analyses suggest that at the margin the activities that student service expenditures fund influence graduation rates much more for students with lower entrance test scores. ${ }^{14}$

Turning next to a comparison of school which receive lower levels and higher levels of Pell Grant expenditures per student (columns 4 and 5), the increase in the sixyear graduation rate of increasing student service expenditures by $\$ 500$ per student is only 0.2 percentage points at the former institutions, but 1.1 percentage points at the latter institutions. The marginal impact of an increase in instructional expenditures per student on the graduation rate is slightly smaller at the former institutions ( 0.2 percentage points) than it is at the latter institutions ( 0.5 percentage points. And, in the simulations that reallocate $\$ 500$ per student from the instructional to student service expenditures, we find

\footnotetext{
${ }^{14}$ Another way of making the same point is to say that we estimate that the proportion of our observations for which the marginal effect of student services expenditures was statistically significantly greater than zero was 0.77 for the low SAT schools and 0 for the high SAT schools. For this test, marginal effects were calculated analytically, and standard errors were obtained using the Delta Method (George Casella and Roger Berger (2001), p. 240)
} 
that the graduation rates at the higher Pell Grant institutions would increase by about 0.5 percentage points but those at the lower Pell Grant institutions would fall by a very small amount (0.03 percentage points) ${ }^{15}$ These results suggest that at the margin the activities that student service expenditures fund influence persistence rates much more for students coming from lower-income families.

The next three columns present analyses separately for bachelors, masters, and doctoral institutions. The marginal impact of an increase in student service expenditures of $\$ 500$ per student is larger at the bachelors' institutions (1.1 percentage points) than it is at the masters' institutions (0.9 percentage points), which in turn is larger than it is at the doctoral institutions ( 0.7 percentage points). This may reflect that the students in the most need of a supportive student service expenditure environment voluntarily select to attend smaller academic institutions. Given this finding, it is not surprising that in our reallocations simulations, on average the greatest positive effect of the reallocation occurs at the bachelors' institutions.

Briefly noting two other results in this table, academic support service expenditures have a statistically significant positive impact on graduation rates only in the higher SAT, the PhD, and the private institution subsamples; in these cases the marginal effect of an increase in academic support service expenditures of $\$ 500$ is about ( 0.5 to 1.0 percentage points). In contrast, increases in budgeted research expenditures per student have statistically significant negative effects on graduation rates primarily at the higher SAT level, the higher level of Pell Grant recipient, the $\mathrm{PhD}$, and the public institutions in our sample.

\footnotetext{
${ }^{15}$ Similarly to above, we estimate that the proportion of our observations for which the marginal effect of student service expenditures was statistically significantly greater than zero was 0.56 for the high Pell Grant dollars per student schools, but 0 for the low Pell Grant dollar schools.
} 


\section{Empirical Extensions}

Two empirical extensions of our analysis warrant being briefly reported. First, another way to analyze the data is to allow the impact of the explanatory variables to vary with the current level of an institution's six-year graduation rate. We use an econometric method called unconditional quantile regression to do this. ${ }^{16}$ This method allows us to illustrate how the impact of the marginal effects of changing instructional and student service expenditures per student vary at different points in the current institutional graduation rate distribution.

Estimates of the coefficients of the student services and instructional expenditure variables that we obtained when we used this method, as well as the marginal effect of increasing expenditures in each category by \$500 per student, holding all other variables constant, and the marginal effect of increasing student service expenditures and decreasing instructional expenditures simultaneously by \$500 per student appear in table $4^{17}$

Quite strikingly, these estimates suggest that the marginal effect of increasing student service expenditures by $\$ 500$ per student on graduation rates is larger at low current graduation rate schools than it is at higher current graduation rate schools. The effect is an increase of greater than 2.0 percentage points in the graduation rate for institutions at which the graduation rate is initially 50 percent or less. It declines monotonically with the initial graduation rate after then and is less than 0.5 percentage points once the $70^{\text {th }}$ percentile in the graduation rate distribution is reached. In contrast, the marginal effect of

\footnotetext{
${ }^{16}$ See Sergio Firpo, Nicole M. Fortin and Thomas Lemieux (2007) for technical details. We use the second method that they propose

${ }^{17}$ The other variables included in the models are the same as those found in column 3 of table 2, including academic support expenditures and budgeted research expenditures per student.
} 
increasing instructional expenditures by $\$ 500$ per student on the graduation rate is greater than 0.9 percentage points for institutions between the $15^{\text {th }}$ and $80^{\text {th }}$ percentile in the graduation rate distribution, but the effect is much smaller for lower and higher initial graduation rate institutions. As a results of these two patterns of estimated effects, if one reallocated \$500 per student from instructional expenditures to student service expenditures, we estimate that this would increase an institution's graduation rate by more than 1 percentage point if the institution was in the lowest 60 percent of institutions in terms of its graduation rate initially,, but for higher initial graduation rates, the effect of the reallocation would quickly approach zero or become negative.

Our second extension is to re estimate equation (1) using an institutions persistence rate, the fraction of its first-year full-time students who enroll at the institution for their second year as the dependent variables. Information on institutional persistence rates comes from the College Board's Annual Survey of Colleges: Standard Research Tape. Estimates of the coefficients of the student service and instructional expenditure variables derived from estimating this equation, as well as the marginal effects of simulating the impacts of $\$ 500$ increases in expenditure per student for the two categories, for various subsamples of the data, appear in Table $5 .{ }^{18}$ The sample size analyzed in this table are somewhat smaller than those reported in table 3; the drop off in sample size is higher for low SAT institutions than it is for high SAT institutions and higher for high Pell Grant dollars per student institutions than it is for lower Pell Grant dollars per student institutions.

\footnotetext{
${ }^{18}$ When we estimate the persistence equations only a single year's lagged value of the expenditure category and Pell Grant expenditure variables are used.
} 
Similar to the graduation rate equations, the marginal effects of increasing student service expenditures by $\$ 500$ per student on an institution’s persistence rate is higher for lower SAT schools higher Pell Grant dollars per student schools. But the magnitudes of these effects are much smaller than they are on the six-year graduation rates. Other factors held constant, an increase in student service expenditures of \$500 per student would increase the persistence rate at the lower SAT schools by 0.7 percentage points and at the higher Pell Grant dollar schools by only 0.1 percentage points. While student service expenditures matter, they do not seem to matter much for enhancing first year persistence rates as they do for enhancing six-year graduation rates.

Table 6 reports the results when we use unconditional quantile regression methods to analyze the persistence rate data. Similar to the graduation rate analyses reported in table 4, the marginal impact on persistence rates of an increase in student service expenditures of $\$ 500$ per student is largest for the institutions whose initial persistence rates are in the lower half of the institutions in our sample and our reallocation simulations suggest that improvements in graduation rates would occur primarily for institutions whose initial persistence rates were below the median in the sample. ${ }^{19}$

\section{Concluding Remarks}

Student service expenditures influence graduation and first-year persistence rates. They matter more for students at schools with lower entrance test scores than they do at schools with higher entrance test scores and the matter more at schools that have a larger number of Pell Grant dollars per undergraduate student than they do at schools that have

\footnotetext{
${ }^{19}$ One extension that we did not pursue was the estimation of graduation rate equations using "stochastic frontier methods". Kokkelenberg, Sinha, Porter and Blose (2008) have shown that while the estimation of four-year and five-year graduation rate equations are sensitive to the use of such methods, the estimation of six-year graduation rate equations are not.
} 
a smaller number of Pell Grant dollars per student. And, perhaps another way of saying the same thing, they matter more for schools that have lower graduation and persistence rates than they do for schools that have higher graduation and persistence rates.

Our simulations suggest that reallocating some funds from instructional expenditures to student service expenditures would enhance graduation and persistence rates at the former types of schools. Institutions with higher entrance test scores and lower levels of Pell Grant dollars per student would not see their graduation rates increase very much if they performed similar reallocations; put simply these institutions, which tend to be the higher persistence and graduation rate institutions probably have already achieved the correct balance of expenditures between instructional and student service expenditures.

Our finding that enhancing student service expenditures, even at the expense of reducing instructional expenditures, may enhance graduation rates at some institutions is not a call by us for institutions to do this. Student service expenditures cover a wide range of categories and the IPEDs data that we have used in this paper do not permit us to analyze which of these subcategories of expenditures are the ones that matter. But our findings do suggest that these institutions should be sensitive to the issue and that research is needed to determine which categories of student service expenditures are the ones that matter.

Perhaps our most disturbing finding is that all other things, including instructional expenditures per student constant, higher levels of budgeted research expenditures per student appear to be associated with lower graduation rates. We have speculated, but the IPEDs data do not permit us to verify this speculation, that this relationship arises because institutions with higher levels of budgeted research are also institutions in which 
a greater share of instructional expenditures are devoted to departmental research. Given the social concerns associated with the increasing costs of higher education, we would suggest that it is in the social interest for academic institutions to address what the appropriate share of departmental research should be in their instructional expenditure budgets. 


\section{References}

Alexander Astin, What Matters in College: Four Critical Years Revisited (San Francisco CA: Jossey-Bass, 1993)

Gary L. Blose, John D. Porter, and Edward C. Kokkelenberg, “The Effect of Institutional Funding Cuts on Baccalaureate Graduation Rates in Public Higher Education” in Ronald G. Ehrenberg ed. What's Happening to Public Higher Education?: The Shifting Financial Burden (Baltimore MD: The Johns Hopkins University Press, 2007)

George Casella and Roger Berger, Statistical Inference ( $2^{\text {nd }}$ edition) (Duxbury Press, 2001)

James S. Coleman et. al. Equality of Educational Opportunities (Washington DC: U.S. Office of Education, 1966)

Jill Constantine, “The Effect of Attending Historically Black Colleges and Universities on Future Wages of Black Students”, Industrial and Labor Relations Review 48 (April 1995): 531-546

Robert Donlan and Robert Schmidt, “Modeling Institutional Production of Higher Education”, Economics of Education Review 13 (September 1994): 197-213

Serio Firpo, Nicole M. Fortin and Thomas Lemieux, “Unconditional Quantile Regressions”, National Bureau of Economic Research Technical Working Paper No. 339 (Cambridge, MA: July 2007)

Hans De Groot et. al., “The Cost Structure of American Research Universities”, Review of Economics and Statistics 73 (August 1991): 424-431 
Ronald G. Ehrenberg, Dominic J. Brewer, Adam Gamoran, and J Douglas Willms, “Class Size and Student Achievement”, Psychological Science in the Public Interest 2 (May 2001): 1-30

Ronald G. Ehrenberg and Donna Rothstein, “Do Historically Black Colleges and Universities Confer Unique Advantages of Students? An Initial Analysis”, in Ronald G. Ehrenberg ed. Choices and Consequences: Contemporary Policy Issues in Economics (Ithaca NY: ILR Press, 1994)

Roland G. Fryer Jr. and Michael Greenstone, “The Causes and Consequences of Attending Historically Black Colleges and Universities”, National Bureau of Economic Research Working Paper No. 13036 (Cambridge MA: April 2007)

Ann Gansmeyer -Topf and John Schul, “Institutional Selectivity and Institutional Expenditures: Examining Organizational Factors that Contribute to Retention and Graduation”, Research on Higher Education 47 (December 2006): 213-242

Edward C Kokklenberg, Esha Sinha, John D. Porter, and Gary L. Blose, “The Efficiency of Private Universities as Measured by Graduation Rates”, Cornell Higher Education Research Institute Working Paper No. 113 (Ithaca NY, July 2008) Tamar Lewin, “Staff Jobs on Campus Outpace Enrollment”, New York Times (April 21, 2009)

Gary R. Pike, John C. Smart, George D. Kuh, and John C. Hayek, “Educational Expenditures and Student Engagement: When Does Money Matter?” Research in Higher Education 47 (November 2006):847-872 
John F. Ryan, “The Relationship Between Institutional Expenditures and Degree Attainment at Baccalaureate Colleges”, Research in Higher Education 45 (March 2004): $97-114$

Jane Wellman et. al. The Growing Imbalance: Recent Trends in U.S Postsecondary Education Finance (Washington DC: Delta Cost Project, 2008)

Jane Wellman et. al. Trends in College Spending: Where Does the Money Come From and Where Does it Go? (Washington DC: Delta Cost Project, 2009) 
Table 1

Descriptive Statistics

\begin{tabular}{lcccccccccc}
\hline \hline & & Low & High & Low & High & & & & & \\
& Total & SAT & SAT & Pell & Pell & Bachelors & Masters & PhD & Public & Private \\
& $(1)$ & $(2)$ & $(3)$ & $(4)$ & $(5)$ & $(6)$ & $(7)$ & $(8)$ & $(9)$ & $(10)$ \\
\hline Grad Rate & 0.55 & 0.43 & 0.65 & 0.64 & 0.45 & 0.56 & 0.50 & 0.61 & 0.47 & 0.59 \\
& $(0.17))$ & $(0.12)$ & $(0.14)$ & $(0.15)$ & $(0.13)$ & $(0.19)$ & $(0.14)$ & $(0.17)$ & $(0.15)$ & $(0.17)$ \\
Student Exp & 2779 & 1980 & 3514 & 3348 & 2193 & 4458 & 1884 & 1686 & 1128 & 3714 \\
& $(9288)$ & $(1282)$ & $(12770)$ & $(12684)$ & $(2975)$ & $(15167)$ & $(1108)$ & $(1419)$ & $(453)$ & $(11514)$ \\
Instruction Exp & 9689 & 6087 & 12966 & 12592 & 6701 & 12155 & 6452 & 11943 & 6639 & 11415 \\
& $(31251)$ & $(2827)$ & $(42962)$ & $(43292)$ & $(5991)$ & $(51052)$ & $(2899)$ & $(8987)$ & $(2703)$ & $(38951)$ \\
Academic Exp & 2456 & 1438 & 3389 & 3320 & 1567 & 3078 & 1512 & 3280 & 1713 & 2876 \\
& $(8447)$ & $(846)$ & $(11602)$ & $(11700)$ & $(1549)$ & $(13589)$ & $(818)$ & $(3908)$ & $(973)$ & $(10523)$ \\
Research Exp & 2682 & 704 & 4045 & 3738 & 1299 & 1444 & 461 & 6442 & 2179 & 3318 \\
& $(8238)$ & $(1788)$ & $(10390)$ & $(10534)$ & $(2838)$ & $(11723)$ & $(1389)$ & $(9017)$ & $(3554)$ & $(11699)$ \\
Pell Exp & 779 & 1019 & 563 & 464 & 1103 & 873 & 798 & 579 & 862 & 732 \\
& $(454)$ & $(470)$ & $(311)$ & $(150)$ & $(434)$ & $(513)$ & $(390)$ & $(400)$ & $(439)$ & $(456)$ \\
Median SAT & 1072 & 973 & 1162 & 1137 & 1005 & 1077 & 1031 & 1147 & 1041 & 1090 \\
& $(122)$ & $(61)$ & $(92)$ & $(115)$ & $(89)$ & $(136)$ & $(85)$ & $(123)$ & $(101)$ & $(129)$ \\
Persistence & 0.77 & 0.70 & 0.82 & 0.82 & 0.71 & 0.76 & 0.74 & 0.82 & 0.75 & 0.78 \\
& $(0.10)$ & $(0.09)$ & $(0.08)$ & $(0.08)$ & $(0.09)$ & $(0.12)$ & $(0.09)$ & $(0.087)$ & $(0.09)$ & $(0.11)$ \\
Observations & 3926 & 1837 & 2044 & 1991 & 1935 & 1429 & 1667 & 830 & 1419 & 2507 \\
\hline Non
\end{tabular}

Notes: Standard deviations are in parentheses. Grad Rate is the 6-year graduation rate of each school's freshmen class (Source: Delta Cost/IPEDS). The expenditure variables measure per student dollars spent on student services,

instruction, academic support, and research respectively (Source: Delta Cost/IPEDS). Pell Exp represents the average per student dollars received by an institution through the Pell Grant program (Source: Delta Cost/IPEDS). Median SAT is the average of the 25th and 75th percentile of SAT scores (Source: Delta Cost/IPEDS and College Board). Persistence is the proportion of full-time first year students who persist to the second year at the same institution. (Source: College Board) 
Table 2:

Econometric Estimates of Graduation Rate Equations

\begin{tabular}{|c|c|c|c|}
\hline & (1) & $(2)$ & (3) \\
\hline \multirow[t]{2}{*}{$\begin{array}{l}\text { STUDENT } \\
\end{array}$} & $0.263 * * *$ & $0.163 * * *$ & $0.116^{* *}$ \\
\hline & $(0.0710)$ & $(0.0532)$ & $(0.0452)$ \\
\hline \multirow[t]{2}{*}{ ACADEMIC } & $0.151^{* *}$ & 0.0776 & 0.046 \\
\hline & $(0.0676)$ & $(0.0494)$ & $(0.040)$ \\
\hline \multirow[t]{2}{*}{ RESEARCH } & $0.0278 *$ & -0.0142 & $-0.028 * *$ \\
\hline & $(0.0167)$ & $(0.0140)$ & $(0.013)$ \\
\hline \multirow[t]{2}{*}{ INSTRUCTION } & $0.521 * * *$ & 0.114 & $0.202 * * *$ \\
\hline & $(0.0901)$ & $(0.0764)$ & $(0.068)$ \\
\hline \multirow[t]{2}{*}{ PELL } & $-0.717 * * *$ & $-0.297 * * *$ & $-0.275^{* * *}$ \\
\hline & $(0.108)$ & $(0.0745)$ & $(0.0718)$ \\
\hline \multirow{2}{*}{ UNDERSTUDENT } & & & -0.00108 \\
\hline & & & $(0.00506)$ \\
\hline \multirow[t]{2}{*}{ UNDERSTUDENT2 } & & & 0 \\
\hline & & & (0) \\
\hline \multirow[t]{2}{*}{ GRADSTUDENT } & & & 0.0383 \\
\hline & & & $(0.0249)$ \\
\hline \multirow[t]{2}{*}{ GRADSTUDENT2 } & & & $-2.34 \mathrm{e}-06^{* * *}$ \\
\hline & & & (5.97e-7) \\
\hline \multirow[t]{2}{*}{$\mathrm{HBCU}$} & & $1.225 * * *$ & $1.325 * * *$ \\
\hline & & $(0.225)$ & $(0.173)$ \\
\hline \multirow[t]{2}{*}{ HISPANIC } & & -0.541 & -0.0517 \\
\hline & & $(0.468)$ & $(0.181)$ \\
\hline \multirow[t]{2}{*}{ ASIAN } & & $0.764 * *$ & 0.301 \\
\hline & & $(0.346)$ & $(0.240)$ \\
\hline \multirow[t]{2}{*}{ AMINDIAN } & & -1.418 & $-2.040 * * *$ \\
\hline & & $(0.938)$ & $(0.753)$ \\
\hline \multirow[t]{2}{*}{ BLACK } & & $-0.789 * * *$ & $-0.897 * * *$ \\
\hline & & $(0.254)$ & $(0.210)$ \\
\hline \multirow[t]{2}{*}{ MALE } & & $-0.434 * * *$ & -0.0867 \\
\hline & & $(0.165)$ & $(0.205)$ \\
\hline \multirow[t]{2}{*}{ MEDIANSAT } & & $0.00454 * * *$ & $0.00462 * * *$ \\
\hline & & (0.000358) & (0.000298) \\
\hline \multirow[t]{2}{*}{ Constant } & -6.068 & -4.458 & -1.066 \\
\hline & (5.395) & (5.436) & (5.351) \\
\hline Year Controls & No & Yes & Yes \\
\hline Carnegie Controls & No & Yes & Yes \\
\hline Degree Controls & No & No & Yes \\
\hline Observations & 3926 & 3926 & 3926 \\
\hline R-squared & 0.653 & 0.793 & 0.821 \\
\hline
\end{tabular}

Notes: The SAT and expenditure variables are defined as in Table 1. UNDERSTUDENT, UNDERSTUDENT2,

GRADSTUDENT, and GRADSTUDENT2 represent linear and quadratic terms for the full-time equivalent number of undergraduate and graduate students. Note that the small estimated coefficient of the undergraduate variables is due to the data having been weighted by undergraduate enrollment. HBCU is an indicator for whether an institution is a Historically Black College or University. HISPANIC ASIAN AMINDIAN BLACK and MALE represent the proportion of each demographic group in each institution. Degree controls is a collection of variables indicating the proportion of degrees obtained in each of 15 fields (Agriculture, Architecture, Biological Sciences, Business, Communications, Education, Engineering, Health, Humanities, Legal, Math, Military, Performing Arts, Physical Sciences, Social Sciences). PELL is expressed in thousands of dollars, the enrollment variables are expressed in thousands of students, and MEDIANSAT is expressed in hundreds of points. Carnegie Controls is a collection of variables controlling for the Carnegie Classification of the institution. (Source: Delta Cost/IPEDS database and College Board) Standard errors are clustered at the institution level. *, **, and *** denote significance at the 10 percent, 5 percent, and 1 percent levels respectively. 
Table 3:

Econometric Estimates of Graduation Rate Equations (Subsamples)

\begin{tabular}{|c|c|c|c|c|c|c|c|c|}
\hline & $\begin{array}{l}\text { Total } \\
(1)\end{array}$ & $\begin{array}{c}\text { Low SAT } \\
\text { (2) }\end{array}$ & $\begin{array}{l}\text { High SAT } \\
\text { (3) }\end{array}$ & $\begin{array}{c}\text { Low Poverty } \\
\text { (4) }\end{array}$ & $\begin{array}{c}\text { High Poverty } \\
\text { (5) }\end{array}$ & $\begin{array}{c}\text { Bachelors } \\
\text { (6) }\end{array}$ & $\begin{array}{c}\text { Masters } \\
\text { (7) }\end{array}$ & $\begin{array}{l}\mathrm{PhD} \\
(8)\end{array}$ \\
\hline Student Services & $0.11582 * *$ & $0.24589 * * *$ & 0.06005 & 0.04305 & $0.16605^{* * *}$ & $0.27696 * * *$ & $0.13014 * *$ & 0.09092 \\
\hline Std Error & $(0.04521)$ & $(0.06719)$ & $(0.05209)$ & $(0.05365)$ & $(0.05771)$ & $(0.06715)$ & $(0.0564)$ & $(0.06163)$ \\
\hline Marginal & {$[0.00706]$} & {$[0.01738]$} & {$[0.00317]$} & {$[0.00234]$} & {$[0.01126]$} & {$[0.01134]$} & {$[0.00926]$} & {$[0.00684]$} \\
\hline Instruction & $0.20225^{* * *}$ & $0.19007^{*}$ & $0.22049 * * *$ & $0.17548^{* *}$ & $0.26825 * * *$ & 0.0001 & $0.39036 * * *$ & $0.19663 *$ \\
\hline Std Error & $(0.06805)$ & $(0.10247)$ & $(0.08101)$ & $(0.08154)$ & $(0.09331)$ & $(0.09364)$ & $(0.0786)$ & $(0.10301)$ \\
\hline Marginal & {$[0.00337]$} & {$[0.00394]$} & {$[0.00292]$} & {$[0.00242]$} & {$[0.00528]$} & {$[0]$} & {$[0.00756]$} & {$[0.00235]$} \\
\hline Academic Support & 0.04553 & -0.05695 & $0.11129 * *$ & 0.06701 & 0.00291 & 0.0144 & -0.00295 & $0.11651^{*}$ \\
\hline Std Error & $(0.04033)$ & $(0.05727)$ & $(0.0499)$ & $(0.05263)$ & $(0.05091)$ & $(0.05296)$ & $(0.05408)$ & $(0.06388)$ \\
\hline Marginal & {$[0.00314]$} & {$[-0.00493]$} & {$[0.00598]$} & {$[0.00364]$} & {$[0.00025]$} & [0.001] & {$[-0.00024]$} & {$[0.00522]$} \\
\hline Research & $-0.0276 * *$ & -0.02336 & $-0.04246^{* *}$ & 0.0003 & $-0.03744^{* *}$ & -0.00014 & -0.00222 & $-0.09163^{* * *}$ \\
\hline Std Error & $(0.0131)$ & $(0.01696)$ & $(0.01854)$ & (0.01949) & $(0.01771)$ & $(0.02402)$ & $(0.01706)$ & $(0.02947)$ \\
\hline Marginal & {$[-0.00737]$} & {$[-0.009]$} & {$[-0.00798]$} & {$[0.00007]$} & {$[-0.01243]$} & {$[-0.00004]$} & {$[-0.0009]$} & {$[-0.00586]$} \\
\hline Reallocate & 0.00337 & 0.01327 & -0.00007 & -0.00028 & 0.00542 & 0.01134 & 0.00096 & 0.00433 \\
\hline Observations & 3926 & 1837 & 2044 & 1991 & 1935 & 1429 & 1667 & 830 \\
\hline R-Squared & 0.8211 & 0.4816 & 0.8413 & 0.833 & 0.7248 & 0.8028 & 0.69 & 0.8561 \\
\hline
\end{tabular}

Notes: Standard errors are clustered at the institution level. *, **, and *** denote significance at the 10 percent, 5 percent, and 1 percent levels respectively. 
Table 4:

Unconditional Quantile Regression Results

\begin{tabular}{|c|c|c|c|c|c|c|c|c|c|}
\hline & $\begin{array}{l}\text { 10th } \\
(1)\end{array}$ & $\begin{array}{l}\text { 20th } \\
(2)\end{array}$ & $\begin{array}{l}\text { 30th } \\
\text { (3) }\end{array}$ & $\begin{array}{l}\text { 40th } \\
(4)\end{array}$ & $\begin{array}{c}\text { 50th } \\
(5)\end{array}$ & $\begin{array}{l}\text { 60th } \\
(6)\end{array}$ & $\begin{array}{l}\text { 70th } \\
(7)\end{array}$ & $\begin{array}{c}\text { 80th } \\
(8)\end{array}$ & $\begin{array}{c}90 \text { th } \\
(9)\end{array}$ \\
\hline Student Service Exp & $1.133^{* * *}$ & $1.005 * * *$ & $0.890 * * *$ & $0.760 * * *$ & $0.716^{* * *}$ & $0.415^{*}$ & 0.198 & 0.0873 & 0.268 \\
\hline Std Error & $(0.262)$ & $(0.190)$ & $(0.194)$ & $(0.201)$ & $(0.211)$ & $(0.224)$ & $(0.246)$ & $(0.267)$ & $(0.398)$ \\
\hline Marginal & 0.02132 & 0.028498 & 0.028313 & 0.025236 & 0.022148 & 0.011211 & 0.004208 & 0.001244 & 0.001733 \\
\hline Instruction Exp & 0.552 & $1.076^{* * *}$ & $1.464^{* * *}$ & $1.334^{* * *}$ & $0.951^{*}$ & $1.444^{* * *}$ & $1.430 * * *$ & $1.061^{* *}$ & 0.0556 \\
\hline Std Error & $(0.486)$ & $(0.364)$ & $(0.377)$ & $(0.510)$ & $(0.505)$ & $(0.552)$ & $(0.530)$ & $(0.463)$ & $(0.523)$ \\
\hline Marginal & 0.003026 & 0.008541 & 0.013102 & 0.012336 & 0.008138 & 0.01058 & 0.008143 & 0.003961 & $8.78 \mathrm{E}-05$ \\
\hline Reallocate & 0.018355 & 0.018355 & 0.019403 & 0.013972 & 0.011646 & 0.01313 & -0.00023 & -0.0044 & -0.00291 \\
\hline
\end{tabular}

Notes: Standard errors are clustered at the institution level. We employ the logit method proposed by Firpo, Fortin and Lemieux 2007 to allow for heterogeneous response. *, **, and *** denote significance at the 10 percent, 5 percent, and 1 percent levels respectively. 
Table 5:

Econometric Estimates of Persistence Equations

\begin{tabular}{|c|c|c|c|c|c|c|c|c|}
\hline & $\begin{array}{c}\text { Total } \\
(1)\end{array}$ & $\begin{array}{c}\text { Low SAT } \\
\text { (2) }\end{array}$ & $\begin{array}{l}\text { High SAT } \\
\text { (3) }\end{array}$ & $\begin{array}{c}\text { Low Poverty } \\
\text { (4) }\end{array}$ & $\begin{array}{c}\text { High Poverty } \\
\text { (5) }\end{array}$ & $\begin{array}{c}\text { Bachelors } \\
\text { (6) }\end{array}$ & $\begin{array}{c}\text { Masters } \\
\text { (7) }\end{array}$ & $\begin{array}{c}\mathrm{PhD} \\
(8)\end{array}$ \\
\hline Student Services & 0.005416 & $0.119 * *$ & -0.0166 & -0.0255 & 0.0215 & 0.141 & 0.0141 & -0.0366 \\
\hline Std Error & $(0.041423)$ & $(0.0504)$ & $(0.0576)$ & $(0.0575)$ & $(0.0504)$ & $(0.0876)$ & $(0.0637)$ & $(0.06)$ \\
\hline Marginal & [0.000258] & {$[0.00736]$} & {$[-0.00058]$} & {$[-0.00094]$} & [0.00127] & {$[0.00487]$} & {$[0.00081]$} & {$[-0.00186]$} \\
\hline Instruction & $0.144219 * *$ & 0.12 & 0.12 & 0.0706 & $0.292 * * *$ & -0.0114 & $0.230 * * *$ & 0.0989 \\
\hline Std Error & $(0.06193)$ & $(0.0899)$ & $(0.0795)$ & $(0.0792)$ & $(0.0925)$ & $(0.096)$ & $(0.0822)$ & $(0.0951)$ \\
\hline Marginal & [0.00193] & [0.00219] & [0.00109] & {$[0.00242]$} & [0.00503] & {$[-0.00016]$} & {$[0.00356]$} & [0.00082] \\
\hline Reallocate & -0.0018064 & 0.005051 & -0.00169 & -0.00166 & -0.00427 & 0.004878 & -0.0031 & -0.00272 \\
\hline Observations & 3338 & 1466 & 1835 & 1777 & 1561 & 1231 & 1375 & 732 \\
\hline R-Squared & 0.9121 & 0.709 & 0.940 & 0.926 & 0.879 & 0.786 & 0.747 & 0.912 \\
\hline
\end{tabular}

Notes: Standard errors are clustered at the institution level. *, **, and *** denote significance at the 10 percent, 5 percent, and 1 percent levels respectively. 
Table 6:

Unconditional Quantile Regression Results (Persistence Equations)

\begin{tabular}{|c|c|c|c|c|c|c|c|c|c|}
\hline & $\begin{array}{l}\text { 10th } \\
(1)\end{array}$ & $\begin{array}{l}\text { 20th } \\
(2)\end{array}$ & $\begin{array}{c}\text { 30th } \\
(3)\end{array}$ & $\begin{array}{l}\text { 40th } \\
(4)\end{array}$ & $\begin{array}{c}\text { 50th } \\
(5)\end{array}$ & $\begin{array}{c}\text { 60th } \\
(6)\end{array}$ & $\begin{array}{c}\text { 70th } \\
(7)\end{array}$ & $\begin{array}{c}\text { 80th } \\
(8)\end{array}$ & $\begin{array}{c}\text { 90th } \\
(9)\end{array}$ \\
\hline Student Service Exp & $0.933 * * *$ & $0.956 * * *$ & $0.525 * * *$ & $0.363 * *$ & $0.304 * *$ & 0.188 & 0.210 & 0.161 & 0.0297 \\
\hline Std Error & $(0.276)$ & $(0.201)$ & $(0.168)$ & $(0.161)$ & $(0.150)$ & $(0.144)$ & $(0.144)$ & $(0.144)$ & $(0.162)$ \\
\hline Marginal & 0.014642 & 0.0240188 & 0.01941 & 0.014918 & 0.013767 & 0.008998 & 0.009973 & 0.007419 & 0.001162 \\
\hline Instruction Exp & 0.0769 & 0.0646 & 0.364 & 0.414 & 0.186 & 0.189 & 0.333 & 0.0662 & 0.180 \\
\hline Std Error & $(0.465)$ & $(0.367)$ & $(0.319)$ & $(0.317)$ & $(0.273)$ & $(0.222)$ & $(0.225)$ & $(0.220)$ & $(0.228)$ \\
\hline Marginal & 0.000395 & 0.0005089 & 0.003924 & 0.004913 & 0.002382 & 0.002516 & 0.004307 & 0.000812 & 0.001855 \\
\hline Reallocate & 0.014263 & 0.0235116 & 0.015193 & 0.009561 & 0.011151 & 0.006236 & 0.005248 & 0.006522 & -0.00085 \\
\hline
\end{tabular}

Notes: Standard Errors are clustered at the institution level. We employ the logit method proposed by Firpo, Fortin and Lemieux 2007 to allow for

heterogeneous response. *, **, and *** denote significance at the 10 percent, 5 percent, and 1 percent levels respectively. 


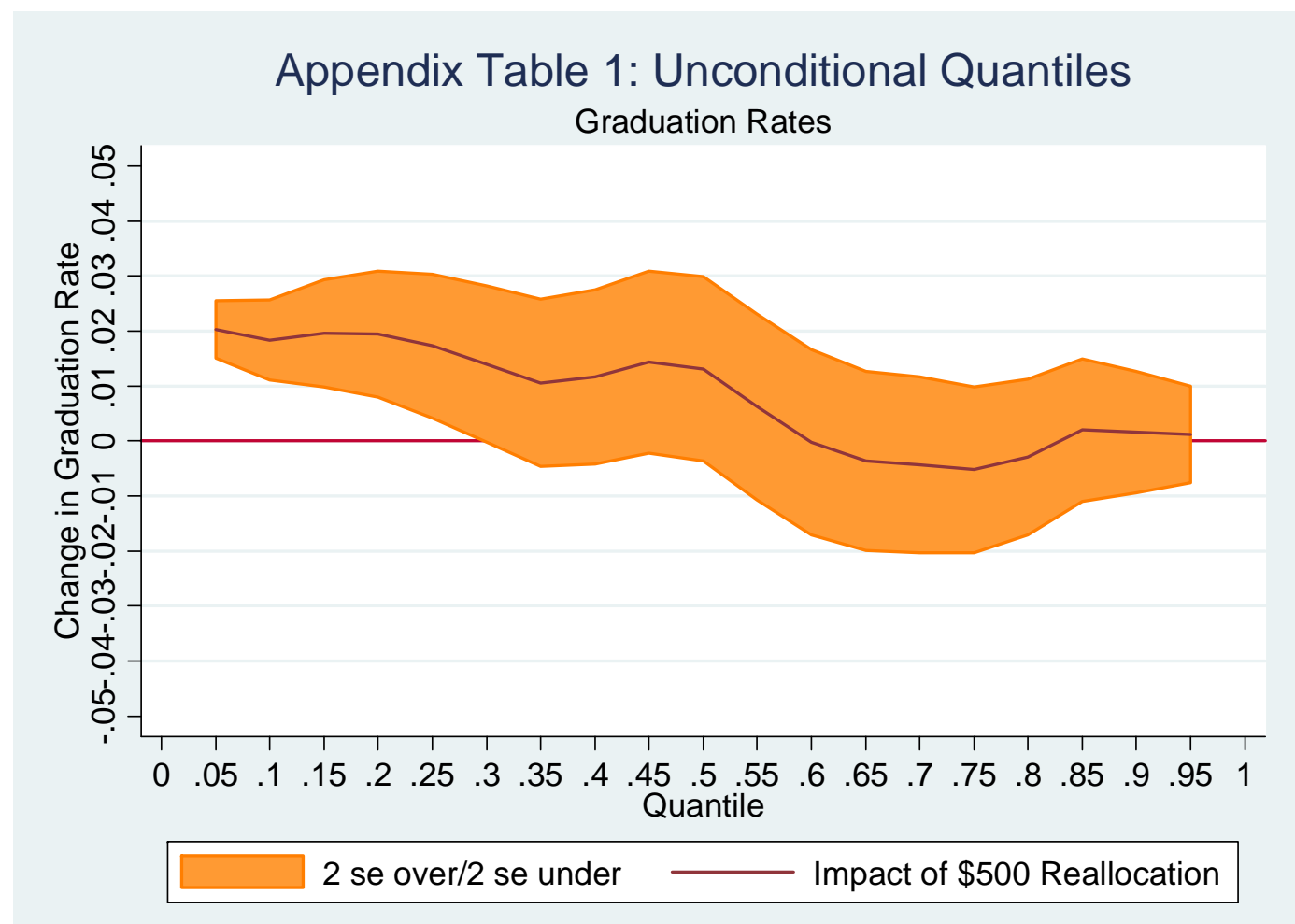

Notes: The shaded region denotes a 95 percent confidence band around the estimated value. 


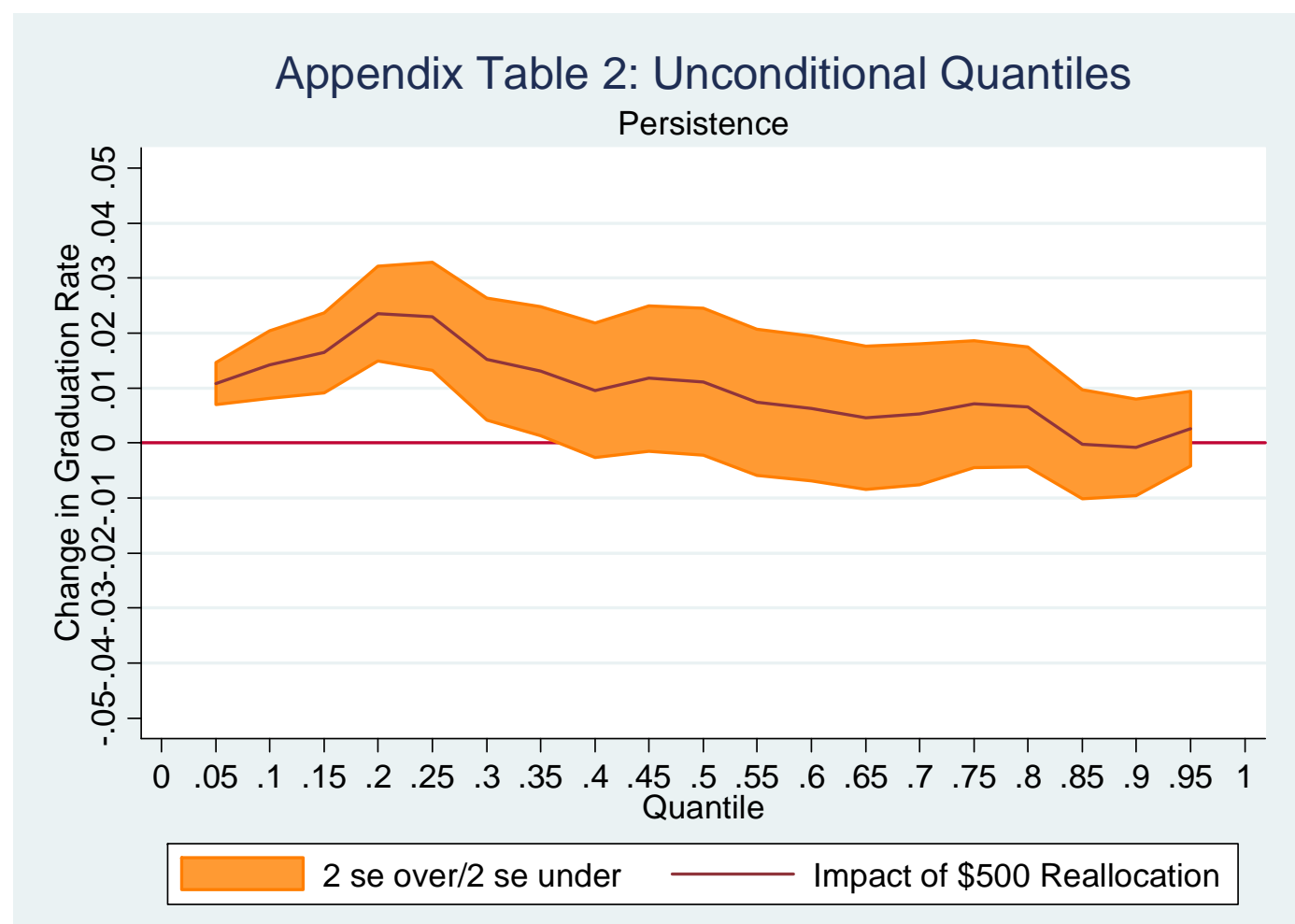

Notes: The shaded region denotes a 95 percent confidence band around the estimated value. 